\title{
Study on quality characteristics of Mandupi added with Ligularia fischeri powder
}

\author{
Bock-Hee Park ${ }^{1}$, Se-Jin Kim ${ }^{1}$, Hee-Sook $\mathrm{Cho}^{2 *}$ \\ ${ }^{1}$ Department of Food and Nutrition, Mokpo National University, Muan 58554, Korea \\ ${ }^{2}$ Department of Culinary Art, Chodang University, Muan 58530, Korea
}

곰취 분말을 첨가한 만두피의 품질 특성

\author{
박복희 ${ }^{1} \cdot$ 김세진 $^{1} \cdot$ 조희숙 ${ }^{2 *}$ \\ ${ }^{1}$ 목포대학교 식품영양학과, ${ }^{2}$ 초당대학교 조리과학부
}

\begin{abstract}
The purpose of this study was to investigate the effect of Ligularia fischeri powder on the functional and sensory characteristics of Mandupi. Various Mandupi samples were prepared with wheat flour by addition of different amounts of Ligularia fischeri powder, and instrumental characteristics and sensory evaluations were then investigated. Based on amylograph data, the composite of Ligularia fischeri powder and wheat flour samples increased its gelatinization temperatures depending on increasing of Ligularia fischeri powder content. However, viscosities at $95^{\circ} \mathrm{C}$ and after 15 min, and maximum viscosity were reduced. In terms of Hunter's color values, $L$ and a values decreased, while b value increased with the increase of Ligularia fischeri powder content. In addition, weight, volume and turbidity of Mandupis prepared with Ligularia fischeri powder were significantly greater than those of control. In terms of textural characteristics, springiness, chewiness and brittleness increased whereas adhesiveness decreased with the addition of Ligularia fischeri powder. Sensory evaluations showed that the overall preference of Mandupi with the addition of $3 \%$ Ligularia fischeri powder was greater than that of wheat flour only.
\end{abstract}

Key words : Ligularia fischeri powder, Mandupi, quality characteristics, color values, sensory evaluations

\section{서 론}

최근 건강에 대한 관심이 높아짐에 따라 식생활 양상이 변화되고 있으며, 이러한 식생활의 변화로 우리나라에서 자생하고 있는 식용식물에 대한 관심 또한 높아지고 있다. 우리나라에서 자생하는 취나물은 수리취, 참취, 개미취, 청 옥취, 미역취, 곰취 등 그 종류가 매우 다양하다. 이중 곰취 (Ligularia fischeri)는 국화과에 속하는 다년생 초본식물로 웅소라고도 하며 곰취라는 이름은 곰이 좋아하는 나물에서 온 것이다. 곰취는 봄에 어린잎을 채취하여 생채, 나물, 쌈

*Corresponding author. E-mail : hscho61@hanmail.net Phone : 82-61-450-1645, Fax : 82-61-450-1641

Received 5 March 2015; Revised 15 July 2015; Accepted 28 July 2015.

Copyright (c) The Korean Society of Food Preservation. All rights reserved.
등으로 식용하고 있으며, chamomile, jacobine, ameleme 등 의 약리성분과 polyphenol 화합물 및 flavonoids가 확인됨에 따라(1) 동물실험 및 분자생물학적 수준에서 곰취의 생리활 성에 관한 연구가 많이 진행되고 있다. 대표적으로 곰취의 항산화 효과(2-5), 항염증 작용(6)과 곰취 메탄올 추출물의 생리활성 및 암세포 증식 억제 효과(7) 등은 이미 과학적으 로 충분히 입증되고 있다. 영양적인 측면에서도 곰취는 각 종 비타민과 무기질을 풍부하게 함유하고 있어서 기능성 식품 소재로 활용가치가 높은 것으로 평가되고 있다(8). 현재 식용식물의 유효성분 분석에 관한 연구가 진행되고는 있으나, 식용식물을 이용한 가공식품의 개발 등에 관한 연 구는 아직 미비한 실정이다

만두는 우리나라 주식류의 한 종류로 하루 세끼의 식사 중 주로 점심이나 저녁에 식사대용으로 먹기도 하지만 간식 으로 혹은 별식으로 남녀노소를 구분하지 않고 즐겨 이용되 고 있는 음식이며, 한국인의 식습관에 가장 적합한 특징으 
로 원료 및 형태에 따라 다양한 제품의 구현이 가능하기 때문에 향후 지속적인 성장이 가능한 품목군으로 평가 되고 있다(9). 냉동식품으로 많이 이용되고 있는 만두는 가정에 서 간편 영양식으로 선호되며, 단체급식에서도 자주 제공 되는 음식 중의 하나로 소비자들의 다양한 요구에 맞는 만두피의 개발이 지속적으로 필요하다(10). 최근엔 다양한 생리활성 효과가 있는 식재료들을 첨가하여 제조한 만두피 에 관한 연구들이 진행되고 있다. 건강에 유익한 기능이 있다고 알려진 천연 소재를 첨가한 만두피에 대한 연구로는 새우 분말을 첨가한 만두피(11), 파래 분말을 첨가한 만두피 (12), 새송이 분말을 첨가한 만두피(13), 비파잎 분말을 첨가 한 만두피(14), 고아미 가루를 첨가한 만두피(15) 등의 품질 특성에 관한 연구가 보고 되었다. 그러나 곰취를 만두피 제조에 활용한 연구는 미흡한 실정이다.

이에 본 연구에서는 곰취가 갖는 우수한 생리기능을 활 용하고자 곰취 분말을 첨가하여 만두피를 제조하고 품질특 성을 평가함으로써 곰취의 이용분야 확대 및 다양한 기능성 만두피 개발을 위한 기초자료를 제공하고자 하였다.

\section{재료 및 방법}

\section{실험재료}

본 실험에 사용된 곰취 분말은 강원도 정선군 백이산에 서 채취하여 분말로 만든 것을 정선군 광덕1리 은향골 마을 쇼핑몰에서 구입하였으며, 80 mesh 체를 통과시켜 실험재 료로 사용하였다. 밀가루는 제면용(Midium wheat flour, Daehan flour mills Co., Ltd., Korea)을 구입하여 사용하였고, 소금은 천일염(Chungjungone, Korea)을 사용하였다.

\section{일반성분 분석}

밀가루와 곰취 분말의 일반성분은 $\mathrm{AOAC}$ 법(16)으로 측 정하였다. 수분함량은 $105^{\circ} \mathrm{C}$ 상압가열건조법, 조단백질은 미량 킬달법(micro-Kjeldahl)으로(질소계수 6.25 를 사용) 분 석하였으며, 조지방 함량은 Soxhlet 추출법, 조회분은 $550^{\circ} \mathrm{C}$ 전기로에서 회화시키는 직접 회화법으로 정량하였다. 탄수 화물은 시료 전체 무게(\%)에서 수분, 회분, 조지방, 조단백 질을 뺀 나머지 값을 \%로 표시하였다.

\section{만두피의 제조}

실험에 사용된 만두피의 곰취 분말 함유량은 예비실험을 거쳐 관능적 특성을 고려하여 총 가루분량의 $0 \%, 1 \%, 3 \%$, $5 \%, 7 \%$ 로 결정하였다. 만두피 반죽은 밀가루 $100 \mathrm{~g}$ 에 소금 $2 \mathrm{~g}$, 물 $40 \mathrm{~g}$ 을 넣어 반죽 한 후 상온에서 30 분간 숙성시킨 뒤 가정용 국수제조기(Aruk Co., Korea)를 사용하여 두께 $1.00 \mathrm{~mm}$, 직경 $7 \mathrm{~cm}$ 의 원형 만두피를 제조하였다. 곰취 분말의 첨가량을 달리하여 제조한 만두피의 배합비는
Table 1과 같다.

Table 1. Formula of Mandupi with varied levels of Ligularia fischeri powder

\begin{tabular}{lccccc}
\hline \multirow{2}{*}{$\begin{array}{c}\text { Ingredients } \\
\text { (g) }\end{array}$} & \multicolumn{5}{c}{ Sample $^{1)}$} \\
\cline { 2 - 6 } & Control & LFP-1\% & LFP-3\% & LFP-5\% & LFP-7\% \\
\hline Flour & 100 & 99 & 97 & 95 & 93 \\
Ligularia fischeri powder & 0 & 1 & 3 & 5 & 7 \\
Sallt & 2 & 2 & 2 & 2 & 2 \\
Water & 40 & 40 & 40 & 40 & 40 \\
\hline
\end{tabular}

${ }^{1)}$ Control, no Ligularia fischeri powder; LFP-1\%, $1 \%$ Ligularia fischeri powder added; LFP-3\%, 3\% Ligularia fischeri powder added; LFP-5\%, 5\% Ligularia fischeri powder added; LFP-7\%, 7\% Ligularia fischeri powder added.

\section{아밀로그래프에 의한 점도 특성}

Amylograph에 의한 시료의 호화양상 측정은 Brabender Micro Visco- Amylograph(Brabender Co., Duisburg, Germany) 를 사용하여 Park과 $\mathrm{Cho}(23)$ 의 방법에 따라 측정하였다. 시료 $65 \mathrm{~g}(14 \% \mathrm{mb}$.)에 증류수 $450 \mathrm{~mL}$ 를 가한 현탁액을 amylograph 호화 용기에 넣고, $30^{\circ} \mathrm{C}$ 에서 $95^{\circ} \mathrm{C}$ 까지 $1.5^{\circ} \mathrm{C} / \mathrm{min}$ 로 호화시킨 후 $95^{\circ} \mathrm{C}$ 에서 15 분간 유지시켜 호화개시온도, 최고점도, $95^{\circ} \mathrm{C}$ 에서의 점도, $95^{\circ} \mathrm{C}$ 에서 15 분 후의 점도 등을 측정하였다.

\section{만두피의 조리특성}

만두피의 조리 시 변화는 Cho와 Kim(17)의 방법으로 분 석하였다. 중량 변화는 만두피 $50 \mathrm{~g}$ 을 끓는물 $400 \mathrm{~mL}$ 에 넣고 3 분간 삶은 후 30 초간 냉수에서 냉각시키고 3 분간 물을 뺀 뒤 만두피의 무게를 측정하였다. 만두피의 수분 흡수율은 조리 후 만두피의 중량에서 생만두피의 중량을 빼고 다시 생만두피의 중량으로 나눈 후 100 을 곱하여 계산 하였다. 삶은 만두피의 부피는 $500 \mathrm{~mL}$ mass cylinder에 300 $\mathrm{mL}$ 의 물을 채운 다음, 수분흡수율을 측정한 만두피를 시료 로 mass cylinder에 넣어 증가하는 물의 부피를 측정하여 구하였다. 만두피 국물의 탁도는 고형물의 용출 정도를 나 타내는 수치로서 조리를 끝낸 국물을 2배로 희석하여 실온 에서 냉각한 후 분광광도계(UV-1601PC, Shimadzu, Japan) 를 사용하여 $675 \mathrm{~nm}$ 에서 흡광도를 측정하였다. 모든 실험 은 3회 반복하여 실시하여 그 결과는 평균값을 구하여 나타 내었다.

\section{만두피의 색도}

만두피의 색도는 만두피를 끓는 물에 넣고 3 분간 삶은 후 물을 뺀 뒤 측정용기에 담아서 색차계(CR-200, Minolta, Tokyo, Japan)를 이용하여 밝기(L, lightness), 적색도(a, redness), 황색도(b, yellowness) 값을 5 회 반복 측정하고 그 평균값으로 나타내었다. 이 때 사용된 표준백색판(standard 
plate)의 $\mathrm{L}, \mathrm{a}, \mathrm{b}$ 값은 $90.5,1.3,3.5$ 이었다.

\section{만두피의 조직감}

만두피의 조직감 특성은 두께 $1.00 \mathrm{~mm}$, 직경 $7 \mathrm{~cm}$ 의 원형 만두피를 끓는 물에서 삶은 후 물기를 뺀 뒤 rheometer(COMPAC-100П, Sun Sci. Co., Tokyo, Japan)를 이용하여 10 회 반복 측정하였다. 이때의 측정조건은 distance $5 \mathrm{~mm}$, adaptor type circle, plunger $\phi 50 \mathrm{~mm}$ cylinder, table speed $120 \mathrm{~mm} / \mathrm{min}$, deformation ratio $90 \%$ 의 조건으로 하여 경도(hardness), 탄력성(springiness), 응집성(cohesiveness), 씹힘성(chewiness) 및 부착성(adhesiveness)의 값으로 나타 내었다.

\section{관능적 특성 평가}

만두피의 관능검사는 훈련을 통해 선발한 관능요원, 교 육대학원생 30 명에게 각 특성치에 대해 설명한 후 7 단계 척도법으로 실시하였다. 즉 패널에게 1점에서 7점까지 강 도가 표시된 척도 위에 각 시료마다 정해진 특성의 강도를 표시하도록 하였으며, 관능검사는 오후 3 4시 사이에 실시 하였다. 모든 시료는 조리특성에서와 같은 방법으로 조리 한 후 $2 \times 2 \times 0.1 \mathrm{~cm}^{3}$ 로 잘라 흰색 폴리에틸렌 1 회용 접시에 담아 물과 함께 제공하였다. 평가 항목으로는 만두피의 외 관(색깔의 바람직한 정도, 표면의 매끄러운 정도), 향미(이 취, 곰취 냄새), 입안에서의 느낌(쫄깃쫄깃한 정도, 치아에 달라붙는 정도), 고소한 맛 및 전체적인 기호도이며 5회 반복하여 실시하였다.

\section{통계분석}

자료의 통계처리는 SPSS(14.0, SPSS Inc., Chicago, IL, USA)를 이용하여 평균 및 표준편차를 구하고, 분산분석 (ANOVA)과 Duncan의 다중범위 시험법(Duncan's multiple range test)으로 통계적 유의성을 검증하였다 $(\mathrm{p}<0.05)$.

\section{결과 및 고찰}

\section{일반성분분석}

실험에 사용한 밀가루와 곰취 분말에 대한 일반성분 분 석 결과는 Table 2 와 같다. 밀가루의 수분함량은 $9.31 \%$, 조단백질은 $13.54 \%$, 조지방질은 $1.26 \%$, 회분은 $0.27 \%$, 탄 수화물은 $75.62 \%$ 이고, 곰취 분말의 수분함량은 $7.75 \%$, 조 단백질은 $20.05 \%$, 조지방질은 $5.91 \%$, 회분은 $13.10 \%$, 탄수 화물 $53.19 \%$ 로 나타났다. Park 등(18)은 곰취 분말을 첨가 한 국수의 품질 특성에서 곰취 분말의 조단백질은 $19.05 \%$, 조지방은 $5.90 \%$ 및 조회분은 $13.12 \%$ 로 측정되었다고 보고 하여 본 실험결과에서도 단백질, 지방 및 조회분의 비율이 우수한 것과 비슷한 결과를 보였다.
Table 2. Proximate composition of wheat flours and Ligularia fischeri powder

\begin{tabular}{lcc}
\hline \multirow{2}{*}{$\begin{array}{c}\text { Characteristics } \\
(\%)\end{array}$} & \multicolumn{2}{c}{ Samples } \\
\cline { 2 - 3 } & Wheat flour & Ligularia fischeri powder \\
\hline Moisture & 9.31 & 7.75 \\
Crude protein & 13.54 & 20.05 \\
Crude lipid & 1.26 & 5.91 \\
Crude ash & 0.27 & 13.10 \\
Carbohydrate & 75.62 & 53.19 \\
\hline
\end{tabular}

\section{아밀로그라프에 의한 점도 특성}

곰취 분말의 첨가량에 따른 아밀로그라프의 특성치는 Table 3과 같다. 호화개시 온도는 대조군의 경우 $65.3^{\circ} \mathrm{C}$ 를 보였고, 곰취 분말의 첨가량이 $1,3,5,7 \%$ 로 증가할수록 호화개시온도는 각각 $66.2,67.4,68.3,68.6^{\circ} \mathrm{C}$ 로 약간씩 증가 하는 경향을 보여 곰취를 첨가함으로써 밀가루 내 전분의 호화를 지연시킴을 알 수 있었다. 이러한 결과는 대체분을 증가시키면 단백질, 지방 등의 성분이 전분입자를 둘러싸 기 때문에 전분의 팽윤이 늦어진다는 연구와 관련성이 있는 것으로 생각된다 $(19,20)$. 비파잎 만두피에서도 부재료의 첨 가량이 증가될수록 비파 분말이 함유하고 있는 칼숨, 마그 네슘, 철분, 아연 등의 무기질이 증가됨으로 인해 호화온도 가 점진적으로 증가하는 경향을 보였다고 보고하여 비슷한 경향이었다(14). 한편 볶은 콩가루 첨가를 달리하여 만두피 의 특성을 연구한 Pyun 등(21)은 볶은 콩가루를 1 10\%까지 첨가하여 호화개시온도를 측정한 결과 대조군이 $59.5^{\circ} \mathrm{C}$ 였 고, 3 10\% 농도를 첨가한 실험구들은 호화개시온도가 모 두 $59.0^{\circ} \mathrm{C}$ 로 본 연구와는 다른 경향을 보였다. 최고점도는 대조군의 경우 392 B.U.로 나타났으나 곰취 분말 첨가량이 증가할수록 $375,374,367$ 및 365 B.U.로 낮아졌다. 볶은 콩가루를 첨가한 만두피의 연구에서는 볶은 콩가루 첨가 비율이 증가할수록 최고 점도가 감소한다고 보고하였고, Park 등(10)은 강황 분말의 첨가량이 증가될수록 만두피의 최고 점도는 감소되는 경향을 보였다고 보고하여 본 결과와 일치하였다. 최고점도와 $95^{\circ} \mathrm{C}$ 에서 15 분 후 점도와의 차이 의 경우 대조군이 가장 낮았고, 곰취 분말의 첨가량이 증가 될수록 높게 나타났다. Oda 등(22)은 최고점도와 $95^{\circ} \mathrm{C}$ 에서 15 분 후 점도 차이가 클수록 식미가 좋아진다고 보고한 바 있어, 본 연구의 곰취 만두피에서 곰취 분말 첨가군이 대조군보다 기호도가 더 높을 것으로 사료된다.

\section{만두피의 조리특성}

곰취 분말의 첨가량을 달리하여 제조한 만두피의 조리특 성은 Table 4와 같다. 만두피의 조리 후 중량은 곰취 분말의 첨가량이 증가함에 따라 유의하게 증가하는 것으로 나타났 다. 즉, 대조군은 조리 후 중량이 $43.62 \mathrm{~g}$ 을 보였고, 1,3 , 5 및 $7 \%$ 첨가군은 각각 $47.80,48.45,49.23$ 및 $50.12 \mathrm{~g}$ 증가하 
는 것으로 나타났다. 볶은 콩가루(21)나 비파잎 분말을 첨가 하여 제조한 연구결과(14)와 비슷한 경향으로 대조군에 비 해 유의적으로 모두 높게 나타났다. 조리 후 부피의 변화는 대조군의 경우 $27.55 \mathrm{~mL}$ 에서 1,3 및 $5,7 \%$ 첨가의 경우 $31.75,32.96$ 및 $33.45,33.58 \mathrm{~mL}$ 로 대조군 보다는 유의하게 증가했으나 곰취 분말을 첨가시킨 군간에 유의적인 차이는 없었다. 면의 조리 후 중량, 부피 및 수분흡수율은 밀가루 전분의 수분흡수력과 연관이 있으며, 면 제조 시 첨가되는 부재료의 종류와 형태에 따라 면의 품질특성은 상이한 것으 로 사료된다. 조리중 고형분의 손실 정도를 나타내는 국물 의 탁도는 대조군이 0.59 로 가장 낮은 값을 보였고, 1,3 . 5 및 7\% 첨가의 경우 각각 $0.61,0.64,0.66$ 및 0.71 로 유의적 으로 증가하는 경향을 보였다. 이러한 결과는 제면시 첨가 물질의 첨가량이 증가할수록 손실량이 커져서 탁도가 높게 나타났다는 보고들(18,23-25)과 일치하였다.

\section{만두피의 색도}

곰취 분말의 첨가량을 달리하여 제조한 만두피의 색도를 측정한 결과는 Table 5 와 같다. 곰취 분말을 첨가하지 않은 대조군의 명도 $(\mathrm{L})$ 는 73.11 , 적색도 $(\mathrm{a}$ 값)는 -1.13 , 황색도 $(\mathrm{b}$ 값)는 8.55 로 나타났다. 명도(L값)는 곰취 분말의 첨가량이 증가할수록 $62.64,59.61,49.26$ 및 43.52로 대조군에 비해 유의적으로 감소되어 만두피의 밝기가 떨어지는 것으로 나타났다. 이러한 결과는 대체분의 첨가 비율이 높을수록 복합분의 밝기가 떨어진다는 볶은 콩가루를 첨가한 연구 (21), 비파잎 분말을 첨가한 연구(14) 및 마가루를 첨가한 연구(23)의 결과와 유사한 경향을 나타내었다. 적색도(a값) 는 곰취 분말의 첨가량이 증가할수록 유의적으로 감소하는 경향을 보였으며 모두 음(-)을 나타내어 녹색의 방향으로 기울어졌다. 이는 곰취 분말 첨가 매작과의 경우 첨가량이 증가할수록 유의적으로 적색도(a값)가 감소하여 어둡고 진

Table 3. The effect of Ligularia fischeri powder on the pasting properties by amylograph

\begin{tabular}{lccccc}
\hline \multirow{2}{*}{ Characteristics } & \multicolumn{5}{c}{ Sample $^{1 \text { l }}$} \\
\cline { 2 - 6 } & Control & LFP-1\% & LFP-3\% & LFP-5\% & LFP-7\% \\
\hline Gelatinization temperature $\left({ }^{\circ} \mathrm{C}\right)$ & $65.3 \pm 1.13^{\mathrm{c} 2}$ & $66.2 \pm 1.22^{\mathrm{b}}$ & $67.4 \pm 1.20^{\mathrm{a}}$ & $68.3 \pm 1.31^{\mathrm{a}}$ & $68.6 \pm 1.42^{\mathrm{a}}$ \\
Viscosity at $95^{\circ} \mathrm{C}$ (B.U.) & $357 \pm 2.41^{\mathrm{a}}$ & $338 \pm 2.12^{\mathrm{b}}$ & $331 \pm 1.31^{\mathrm{b}}$ & $320 \pm 1.20^{\mathrm{c}}$ & $315 \pm 1.12^{\mathrm{d}}$ \\
Viscosity at $95^{\circ} \mathrm{C}$ after 15 min (B.U.) & $292 \pm 0.12^{\mathrm{a}}$ & $230 \pm 1.02^{\mathrm{b}}$ & $222 \pm 1.13^{\mathrm{c}}$ & $213 \pm 0.15^{\mathrm{cd}}$ & $200 \pm 0.13^{\mathrm{d}}$ \\
Maximum viscosity (B.U.) & $392 \pm 1.01^{\mathrm{a}}$ & $375 \pm 1.12^{\mathrm{b}}$ & $374 \pm 1.12^{\mathrm{b}}$ & $367 \pm 1.11^{\mathrm{c}}$ & $365 \pm 1.12^{\mathrm{d}}$ \\
\hline
\end{tabular}

${ }^{1)}$ Control, no Ligularia fischeri powder; LFP-1\%, $1 \%$ Ligularia fischeri powder added; LFP-3\%, 3\% Ligularia fischeri powder added; LFP-5\%, 5\% Ligularia fischeri powder added; LFP-7\%, 7\% Ligularia fischeri powder added.

${ }^{2)}$ Mean \pm SD ( $\left.n=3\right)$. Means with same letter at the row are not significantly different $(\mathrm{p}<0.05)$.

Table 4. The effect of Ligularia fischeri powder on the cooking characteristic of Mandupi

\begin{tabular}{lccccc}
\hline \multirow{2}{*}{ Characteristics } & \multicolumn{5}{c}{ Sample } \\
\cline { 2 - 6 } & Control & LFP-1\% & LFP-3\% & LFP-5\% & LFP-7\% \\
\hline Weight gain (g) & $43.62 \pm 1.12^{\mathrm{c} 2)}$ & $47.80 \pm 1.25^{\mathrm{b}}$ & $48.45 \pm 1.21^{\mathrm{a}}$ & $49.23 \pm 1.15^{\mathrm{a}}$ & $50.12 \pm 1.21^{\mathrm{a}}$ \\
Volume (mL) & $27.55 \pm 0.03^{\mathrm{b}}$ & $31.75 \pm 1.01^{\mathrm{a}}$ & $32.96 \pm 1.21^{\mathrm{a}}$ & $33.45 \pm 1.25^{\mathrm{a}}$ & $33.58 \pm 1.31^{\mathrm{a}}$ \\
Water absorption (\%) & $62.05 \pm 2.31^{\mathrm{c}}$ & $82.55 \pm 3.02^{\mathrm{b}}$ & $85.73 \pm 3.05^{\mathrm{a}}$ & $86.12 \pm 3.15^{\mathrm{a}}$ & $87.12 \pm 3.20^{\mathrm{a}}$ \\
Turbidity & $0.59 \pm 0.01^{\mathrm{c}}$ & $0.61 \pm 0.02^{\mathrm{b}}$ & $0.64 \pm 0.03^{\mathrm{b}}$ & $0.66 \pm 0.11^{\mathrm{b}}$ & $0.71 \pm 0.15^{\mathrm{a}}$ \\
\hline
\end{tabular}

${ }^{1)}$ Control, no Ligularia fischeri powder; LFP-1\%, 1\% Ligularia fischeri powder added; LFP-3\%, 3\% Ligularia fischeri powder added; LFP-5\%, 5\% Ligularia fischeri powder added; LFP-7\%, 7\% Ligularia fischeri powder added.

${ }^{2)}$ Mean \pm SD ( $\left.\mathrm{n}=3\right)$. Means with same letter at the row are not significantly different $(\mathrm{p}<0.05)$.

Table 5. The effect of Ligularia fischeri powder on the color of Mandupi

\begin{tabular}{lccccc}
\hline \multirow{2}{*}{ Color values } & \multicolumn{5}{c}{ Sample $^{\mathrm{l})}$} \\
\cline { 2 - 6 } & Control & LFP-1\% & LFP-3\% & LFP-5\% & LFP-7\% \\
\hline L (lightness) & $73.11 \pm 1.05^{\mathrm{a} 2)}$ & $62.64 \pm 0.21^{\mathrm{b}}$ & $59.61 \pm 0.02^{\mathrm{c}}$ & $49.24 \pm 0.45^{\text {cd }}$ & $43.52 \pm 0.12^{\mathrm{d}}$ \\
a (redness) & $-1.13 \pm 1.02^{\mathrm{a}}$ & $-1.75 \pm 1.21^{\mathrm{b}}$ & $-2.71 \pm 1.41^{\mathrm{c}}$ & $-2.81 \pm 1.13^{\text {cd }}$ & $-2.91 \pm 1.21^{\mathrm{d}}$ \\
b (yellowness) & $8.55 \pm 1.02^{\mathrm{d}}$ & $15.70 \pm 1.20^{\mathrm{c}}$ & $20.62 \pm 1.11^{\mathrm{b}}$ & $21.55 \pm 1.21^{\mathrm{b}}$ & $23.80 \pm 3.01^{\mathrm{a}}$ \\
\hline
\end{tabular}

${ }^{1)}$ Control, no Ligularia fischeri powder; LFP-1\%, $1 \%$ Ligularia fischeri powder added; LFP-3\%, 3\% Ligularia fischeri powder added; LFP-5\%, 5\% Ligularia fischeri powder added; LFP-7\%, 7\% Ligularia fischeri powder added.

${ }^{2)}$ Mean \pm SD ( $\left.n=5\right)$. Means with same letter at the row are not significantly different $(\mathrm{p}<0.05)$. 
한 녹색의 경향을 띠었다는 보고와 일치하였다(26). 황색도 (b값)는 곰취 분말의 첨가량이 증가할수록 유의적으로 증가 하는 경향을 나타냈다.

\section{만두피의 조직감}

곰취 분말의 첨가량을 달리하여 제조한 만두피의 조직감 특성은 Table 6에 나타난 바와 같다. 만두피의 경도는 대조 군의 경우 $2.42 \mathrm{~g} / \mathrm{cm}^{2}$ 이었으며 곰취 분말을 $1,3,5$ 및 $7 \%$ 로 첨가하였을 때 $2.47,2.49,2.55$ 및 $2.64 \mathrm{~g} / \mathrm{cm}^{2}$ 로 증가하였다. 곰취 분말 첨가량이 증가할수록 유의적으로 경도가 증가하 는 것은 곰취 만두피속의 수분 함량과 만두피의 퍼짐성과 관계가 있는 것으로 사료된다. 즉 퍼짐성이 작아질수록 만 두피의 두께는 증가하고 직경이 감소하므로 경도는 증가하 는 것으로 생각된다(27). 한편, 새송이버섯 분말을 첨가한 만두피(28)의 경도는 버섯 분말 첨가군에 비해 대조군이 유의적으로 높게 나타났다고 보고하여 본 결과와는 차이를 보였다. Kang과 $\operatorname{Kim}(29)$ 은 성분배합에 따른 만두피의 물성 변화에서 첨가량이 적거나 많이 함유되었을 때는 만두피의 경도가 감소함을 보였다고 보고한 바 있어 본 실험의 결과 와는 상이하였는데 이는 첨가물의 종류에 따른 차이라고
사료된다. 만두피의 탄력성은 곰취 분말을 첨가하지 않은 대조군이 가장 낮은 값인 $90.22 \%$ 로 나타났으며, 곰취 분말 $1 \%$ 첨가군은 $91.52,3 \%$ 첨가군은 $93.31,5 \%$ 첨가군은 99.12 , $9 \%$ 첨가군은 $101.10 \%$ 로 나타나 곰취 분말의 첨가량이 증 가할수록 탄력성이 유의적으로 증가하는 경향을 보였다. 만두피의 응집성의 변화는 대조군이 $66.52 \%$ 를 보여 가장 낮은 값을 나타내었으며, 곰취 분말을 $1 \%$ 첨가군은 66.88 , $3 \%$ 첨가군은 $68.12,5 \%$ 첨가군은 $68.96,7 \%$ 를 첨가한 만두 피는 $69.31 \%$ 로 곰취 분말의 첨가량이 증가할수록 응집성은 유의하게 증가하는 경향을 보였다. 씹힘성은 대조군이 $132.22 \mathrm{~g}$ 로 가장 낮은 값을 보였고, $1,3,5$ 및 7\% 농도별로 곰취 분말을 첨가한 첨가군은 씹힘성이 각각 141.31 , $150.59,152.39$ 및 $153.40 \mathrm{~g}$ 로 나타났다. 씹힘성은 곰취 분말 첨가군과 대조군 사이에 유의적인 차이가 있는 것으로 나타 났으며 첨가군 간에는 유의차가 없었다. 만두피의 부착성 은 대조군이 $5.50 \mathrm{~g}$, 곰취 분말 $1 \%$ 첨가군은 $6.12 \mathrm{~g}, 3 \%$ 첨가군은 $7.03 \mathrm{~g}$ 로 나타났으며, $5 \%$ 첨가군은 $8.67 \mathrm{~g}, 7 \%$ 첨가군은 $9.08 \mathrm{~g}$ 으로 곰취 분말의 첨가량이 증가할 수록 응집성과 유사하게 유의적으로 증가하는 것으로 나타났다.

Table 6. Textural properties of Mandupi differing in Ligularia fischeri powder

\begin{tabular}{lccccc}
\hline \multirow{2}{*}{ Characteristics } & \multicolumn{5}{c}{ Sample $^{1)}$} \\
\cline { 2 - 5 } & Control & LFP-1\% & LFP-3\% & LFP-5\% & LFP-7\% \\
\hline Hardness (g/cm $\left.{ }^{2}\right)$ & $2.42 \pm 0.11^{\mathrm{c} 2)}$ & $2.47 \pm 0.15^{\mathrm{b}}$ & $2.49 \pm 0.21^{\mathrm{b}}$ & $2.55 \pm 0.20^{\mathrm{a}}$ & $2.64 \pm 0.32^{\mathrm{a}}$ \\
Springiness (\%) & $90.22 \pm 1.04^{\mathrm{d}}$ & $91.52 \pm 1.21^{\mathrm{c}}$ & $93.31 \pm 1.15^{\mathrm{c}}$ & $99.12 \pm 2.01^{\mathrm{b}}$ & $101.10 \pm 2.22^{\mathrm{a}}$ \\
Cohesiveness (\%) & $66.52 \pm 1.31^{\mathrm{b}}$ & $66.88 \pm 1.35^{\mathrm{a}}$ & $68.12 \pm 2.25^{\mathrm{a}}$ & $68.96 \pm 2.45^{\mathrm{a}}$ & $69.31 \pm 2.61^{\mathrm{a}}$ \\
Chewiness (g) & $132.22 \pm 2.21^{\mathrm{c}}$ & $141.31 \pm 2.55^{\mathrm{b}}$ & $150.59 \pm 3.03^{\mathrm{ab}}$ & $152.39 \pm 3.11^{\mathrm{ab}}$ & $153.40 \pm 3.15^{\mathrm{a}}$ \\
Adhesiveness (g) & $5.50 \pm 0.14^{\mathrm{d}}$ & $6.12 \pm 0.15^{\mathrm{c}}$ & $7.03 \pm 0.17^{\mathrm{b}}$ & $8.67 \pm 1.01^{\mathrm{a}}$ & $9.08 \pm 1.11^{\mathrm{a}}$ \\
\hline
\end{tabular}

${ }^{1)}$ Control, no Ligularia fischeri powder; LFP-1\%, 1\% Ligularia fischeri powder added; LFP-3\%, 3\% Ligularia fischeri powder added; LFP-5\%, 5\% Ligularia fischeri powder added; LFP-7\%, 7\% Ligularia fischeri powder added.

${ }^{2)}$ Mean \pm SD ( $\left.=10\right)$. Means with same letter at the row are not significantly different $(\mathrm{p}<0.05)$.

Table 7. Sensory evaluation score of Mandupi differing in Ligularia fischeri powder

\begin{tabular}{|c|c|c|c|c|c|c|}
\hline \multirow{2}{*}{\multicolumn{2}{|c|}{ Sensory characteristics }} & \multicolumn{5}{|c|}{ Sample $^{1)}$} \\
\hline & & Control & LFP-1\% & LFP-3\% & LFP-5\% & LFP-7\% \\
\hline \multirow{2}{*}{ Appearance } & Color & $5.23 \pm 1.01^{22)}$ & $5.31 \pm 1.02^{\mathrm{a}}$ & $5.45 \pm 1.12^{\mathrm{a}}$ & $5.51 \pm 1.13^{\mathrm{a}}$ & $4.02 \pm 1.22^{b}$ \\
\hline & Smoothness & $6.11 \pm 1.01^{b}$ & $6.16 \pm 1.02^{\mathrm{a}}$ & $6.23 \pm 1.01^{\mathrm{a}}$ & $6.21 \pm 1.11^{\mathrm{a}}$ & $6.20 \pm 1.01^{\mathrm{a}}$ \\
\hline \multirow{2}{*}{ Flavor } & Off-flavor & $2.52 \pm 0.01^{\mathrm{b}}$ & $2.57 \pm 1.01^{\mathrm{a}}$ & $2.59 \pm 1.02^{\mathrm{a}}$ & $2.60 \pm 1.22^{\mathrm{a}}$ & $2.50 \pm 1.02^{b}$ \\
\hline & Ligularia fischeri odor & $1.85 \pm 1.12^{\mathrm{d}}$ & $1.95 \pm 1.22^{\mathrm{c}}$ & $2.02 \pm 2.10^{b}$ & $2.15 \pm 2.11^{\mathrm{b}}$ & $2.21 \pm 1.21^{\mathrm{a}}$ \\
\hline \multirow{2}{*}{ Texture } & Chewiness & $5.25 \pm 0.11^{\mathrm{bc}}$ & $5.35 \pm 1.12^{\mathrm{b}}$ & $5.51 \pm 1.01^{\mathrm{a}}$ & $5.37 \pm 1.21^{\mathrm{ab}}$ & $5.20 \pm 1.13^{\mathrm{c}}$ \\
\hline & Adhesiveness & $5.27 \pm 1.01^{\mathrm{b}}$ & $5.40 \pm 1.15^{\mathrm{a}}$ & $5.50 \pm 2.11^{\mathrm{a}}$ & $5.42 \pm 2.10^{\mathrm{a}}$ & $5.25 \pm 2.05^{\mathrm{a}}$ \\
\hline Taste & Nutty taste & $3.95 \pm 0.11^{\mathrm{d}}$ & $4.12 \pm 0.12^{c}$ & $4.21 \pm 0.41^{\mathrm{a}}$ & $4.20 \pm 0.40^{\mathrm{a}}$ & $4.16 \pm 0.21^{b}$ \\
\hline \multicolumn{2}{|c|}{ Overall acceptability } & $5.43 \pm 1.03^{\mathrm{c}}$ & $5.58 \pm 1.01^{\mathrm{b}}$ & $5.70 \pm 1.13^{\mathrm{a}}$ & $5.40 \pm 1.21^{\mathrm{c}}$ & $5.35 \pm 1.04^{d}$ \\
\hline
\end{tabular}

${ }^{15}$ Control, no Ligularia fischeri powder; LFP-1\%, $1 \%$ Ligularia fischeri powder added; LFP-3\%, 3\% Ligularia fischeri powder added; LFP-5\%, 5\% Ligularia fischeri powder added; LFP-7\%, 7\% Ligularia fischeri powder added.

${ }^{2}$ Mean $\pm \mathrm{SD}(\mathrm{n}=30)$. Means with same letter at the row are not significantly different $(\mathrm{p}<0.05)$. 


\section{만두피의 관능적 특성}

곰취 분말을 첨가하여 조리한 만두피에 대해 외관(색깔, 표면의 매끄러운 정도), 향미(이취, 곰취 분말 특유의 냄새), 입안에서의 느낌(단단한 정도, 쫄깃한 정도, 촉촉한 정도, 치아에 달라붙는 정도), 전체적인 기호도를 기준으로 실시 한 관능적 품질 특성 결과는 Table 7에 나타내었다. 만두피 의 색깔은 대조군에 비해 곰취 분말 $1,3,5 \%$ 첨가군이 유의적으로 높은 점수를 얻었지만, $7 \%$ 첨가군에서는 $4.02 \pm 1.22$ 로 낮아지는 것을 볼 수 있었다. 표면의 매끄러운 정도는 대조군과 곰취 분말 $1 \%$ 첨가군은 유의적으로 낮은 점수를 보였지만 곰취 분말 $3,5,7 \%$ 첨가군은 유의적으로 높은 점수를 보였다. 만두피의 촉촉한 정도는 대조군과 곰 취 분말 첨가군 모두 유의적인 차이를 보이지 않았다. 향미 특성을 볼 때 만두피의 이취는 곰취 분말의 첨가량이 많을 수록 유의적으로 높은 점수를 받았지만 $7 \%$ 첨가군이 $2.50 \pm 1.02$ 의 점수를 보여 가장 낮은 값을 보였다. 만두피의 곰취 특유의 냄새는 곰취 분말의 첨가량이 많아질수록 유의 적으로 높은 점수를 받았다. 만두피의 텍스쳐 특성을 보면 쫄깃한 정도 촉촉한 정도 및 치아에 달라붙는 정도를 평가 한 항목 모두 $3 \%$ 첨가군에서 가장 높은 점수를 받았다. 전반적인 기호도에서는 곰취 분말을 첨가하지 않은 대조군 이 $5.43 \pm 1.03$ 의 점수를 보였고 $3 \%$ 첨가군이 $5.70 \pm 1.13$ 로 높은 점수를 받아 유의적인 차이를 보였다. 이상의 결과로 볼 때 곰취 분말을 첨가하여 만두피를 제조할 경우 $3 \%$ 첨가군이 표면의 매끄러운 정도, 이취, 쫄깃한 정도, 촉촉한 정도, 치아에 달라붙는 정도가 대조군에 비해 높게 평가되 었으며, 전반적으로 바람직한 정도 역시 곰취 분말 $3 \%$ 첨가 군의 기호도가 가장 높게 평가되었다.

\section{요 약}

곰취가 갖는 우수한 생리기능을 활용하고자 곰취 분말을 $0,1,3,5$ 및 $7 \%$ 첨가한 만두피를 제조하여 그 품질특성을 평가함으로써, 다양한 기능성 만두피 개발 및 곰취의 이용 분야 확대를 위한 기초자료를 제공하고자 하였다. 호화개 시온도는 곰취 분말의 첨가량이 증가될수록 점진적으로 증가하는 경향을 보였다. 최고점도, $95^{\circ} \mathrm{C}$ 에서 점도 및 $95^{\circ} \mathrm{C}$ 에서 15 분간 유지한 후의 점도는 곰취 분말의 첨가량이 증가함에 따라 낮아지는 것으로 나타났다. 만두피의 색도 는 곰취 분말 첨가량이 증가함에 따라 명도( $\mathrm{L}$ 값)와 적색도 (a값)는 유의하게 감소하였으며, 황색도(b값)는 각 시료간 에 유의하게 증가되었다. 조리특성에서 곰취 분말을 첨가 한 만두피는 대조군에 비해 중량, 부피, 수분흡수율 등이 모두 높게 나타났다. 만두피의 조직감은 곰취 분말 첨가량 이 증가될수록 경도, 응집성, 씹힘성 및 부착성은 높아졌으 며, 탄력성은 증가하였다. 만두피의 관능검사 결과, 표면의
매끄러운 정도는 대조군이 가장 높은 점수를 나타냈으며, 고소한 맛은 곰취 분말 첨가량이 많아질수록 증가되었다. 전체적인 기호도는 곰취 분말 $3 \%$ 첨가군이 가장 높은 것으 로 평가되었다. 이상의 결과를 종합하여 보면 곰취 분말 첨가는 전체적인 관능평가에 긍정적인 영향을 미치며, 특 히 곰취 분말 $3 \%$ 첨가가 만두피의 기호도를 높일 수 있는 가장 적절한 수준으로 생각된다.

\section{References}

1. Cho SD, Kim GH (2005) Food product development and quality characteristics of Ligularia fischeri for food resources. Korean J Food Preserv, 12, 43-47

2. Chang SK, Kim JH, Oh HS (2008) The development of functional cold buckwheat noodles using biological activity of hot water extracts of Ligularia fischeri and Angelica gigas Nakai. Korean J Food Culture, 23, 479-488

3. Jeong SW, Kim EJ, Hwangbo HJ, Ham SS (1998) Effects of Ligularia fischeri extracts on oxidation of low density lipoprotein. Korean J Food Sci Technol, 30, 1214-1221

4. Park JA, Kim MK (1999) Effect of Korean native plant diet on lipid metabolism, antioxidative capacity and cadmium detoxification in rats. Korean $\mathrm{J}$ Nutr, 32, 353-368

5. Kim DW, Son KH, Chang HW, Bae KH, Kang SS, Kim HP (2004) Anti-inflammatory activity of Sedum kamtschaticum. J Ethnopharmacology, 90, 409-414

6. Kim EY, Baik IH, Kim JH, Kim SR, Rhyu MR (2004) Screening of the antioxidant activity of some medicinal plants. Korean J Food Sci Technol, 36, 333-338

7. Bae JH, Yu SO, Kim YM, Chon SU, Kim BW, Heo BG (2009) Physiological activity of methanol extracts from Ligularia fischeri and their hyperplasia inhibition activity of cancer cell. J Bio Environment Control, 18, 67-73

8. Kim GN, Cho MS, Kwon KW (2010) Analysis growth performance and ascorbic acid contents of Allium victorialis var. platyphyllum, Ligularia fischeri, and $L$. stenocephala under changing light intensity. J Korean For Soc, 99, 68-74

9. Seo JS (2013) Quality characteristics of a dumpling shell with Curcuma longa L. powder added. Korean J Food Preserv, 20, 621-627

10. Park BH, An SA, Cho HS (2014) Quality characteristics of Mandupi added with Curcuma aromatica powder. 
Korean J Food Culture, 29, 348-354

11. Kim KH, Park BH, Cho YJ, Kim SR, Cho HS (2009) Quality characteristics of shrimp flour added dumpling shell. Korean J Food Culture, 24, 206-211

12. Park BH, Ju SM, Cho HS (2010) Effect of Enteromorpha intenstinalis powder addition in the quality of dumpling shell. Korean J Food Preserv, 17, 814-819

13. Kang BH, Shin EJ, Lee SH, Lee DS, Hur SS, Kim SH, Son SM, Lee JM (2011) Quality characteristics of dumpling shell containing Pleurotus eryngii powder. J Korean Soc Food Sci Nutr, 40, 570-574

14. Park ID (2012) Quality characteristics of dumpling shell containing loquat leaf powder. J East Asian Soc Dietary Life, 22, 795-801

15. Kim HA, Lee KH (2013) The quality characteristics of mandupi added with goami powder. J East Asian Soc Dietary Life, 23, 098-106

16. AOAC (1990) Official Method of Analysis 16th ed. Association of Official Analytical Chemists, Washington DC, p 41-57

17. Cho HS, Kim KH (2008) Quality characteristics of Mandupi with skate (Raja Kenojer) flour. Korean J Food Culture, 23, 252-257

18. Park BH, Joo HM, Cho HS (2014) Quality characteristics of dried noodles added with Ligularia fischeri powder. Korean J Food Culture, 29, 205-211

19. Choe HD, Seo HM, Kim SL, Park YG, Lee CH (2003) Effect of $\beta$-glucan on gelatinization of barley starch. Korean J Food Sci Technol, 35, 545-550

20. Kim ML (2006) Antioxative activity of extracts from Gardenia jasminoides and quality characteristics of noodle added Gardenia jasminoides powder. Korean J
Food Cookery Sci, 22, 237-243

21. Pyun JW, Nam HW, Woo IA (2001) A study on the characteristics of mandu-pi differing in roasted soy flour content. Korean J Food Nutr, 14, 287-292

22. Oda M, Yasuda Y, Okazaki S (1980). A method of flour quality assessment for Japanese noodles. Cereal Chem, 57, 253-254

23. Park BH, Cho HS (2006) Quality characteristics of dried noodles made with Dioscorea japonica flour. Korean J Food Cookery Sci, 22, 173-180

24. Song SH, Jung HS (2009) Quality characteristics of noodles (Garakguksu) with Curcuma longa L. powder. Korean J Food Cookery Sci, 25, 199-205

25. Cho HS, Kim KH (2009) Assessment of quality characteristics of dried shrimp noodles for elderly foodservice operations. Korean J Food Cookery Sci, 25, 267-274

26. Park ID (2013) Quality characteristics of Maejakgwas with added Ligularia fischeri powder. J East Asian Soc Dietary Life, 23, 605-612

27. Choi YS, Lee MH, Jhee OH (2011) Quality characteristics of sugar-snap cookies by addition of Curcuma longa L. powder. Korean J Culi Res, 17, 198-208

28. Kang BH, Shin EJ, Lee SH, Lee DS, Hur SS, Kim SH, Son SM, Lee JM (2011) Quality characteristics of dumpling shell containing Pleurotus eryngii powder. J Korean Soc Food Sci Nutr, 40, 570-574

29. Kang KS, Kim BS (2003) Changes of rheology on the dumpling shell by added materials. Korean J Food Preserv, 10, 498-505 